DOI: $10.20472 / T E .2019 .7 .2 .004$

\title{
HOW SKILLED TEACHERS ENABLE SUCCESS IN THEIR TEACHING WITH RESPECT TO INCLUSION AND KNOWLEDGE DEVELOPMENT: A QUALITATIVE STUDY BASED ON TEACHERS' EXPERIENCES OF SUCCESSFUL TEACHING
}

\author{
MIKAEL SEGOLSSON, ÅSA HIRSH
}

\begin{abstract}
:
The study answers the following question: What teaching practices do skilled teachers report as being key to enabling successful teaching with respect to inclusion and knowledge development? The participants in this study where 20 teachers, from 10 Swedish municipalities, who taught 16 to 18 year-old students. The study is based on interviews with (recognised) skilled teachers who possess the ability to include all of their students in everyday teaching practices in such a way that students are motivated to engage in knowledge development, based on their unique abilities. All of the participating teachers are in agreement that good knowledge of the subject being taught is foundational to such teaching, but other abilities are needed if teaching is to be successful. Based on phenomenological theory, this study identifies six themes which complement 'good knowledge of the subject'. The themes relevant to teaching success are: (i) the active and systematic creation of relationships; (ii) demonstration that the teacher wants to be with the student, here and now; (iii) a continual striving to become a better teacher and demonstration of the same; (iv) a sharing of responsibility for learning with the students; (v) the creation of learning opportunities; (vi) the establishment of trust and a sense of security.
\end{abstract}

\section{Keywords:}

Skilled teachers, successful teaching, teaching actions, teaching actions, phenomenology, inclusion, knowledge development

JEL Classification: 129, 121

\section{Authors:}

MIKAEL SEGOLSSON, Jönköping University, Sweden, Email: mikael.segolsson@ju.se ÅSA HIRSH, Jönköping University, Sweden, Email: asa.hirsh@ju.se

\section{Citation:}

MIKAEL SEGOLSSON, ÅSA HIRSH (2019). How skilled teachers enable success in their teaching with respect to inclusion and knowledge development: A qualitative study based on teachers' experiences of successful teaching. International Journal of Teaching and Education, Vol. VII(2), pp. 35-52., 10.20472/TE.2019.7.2.004 


\section{Introduction}

From an international perspective, the question of what characterises successful teaching and the importance of a skilled teacher in the classroom has attracted a great deal of research interest in the past few decades. The results of international research on teaching and learning are comprehensive and of some significance, and we note there is an abundance of research that has identified which factors improve students school grades and which factors positively influence classroom teaching (see Nordenbo et al., 2008; Hattie, 2009; Hargreaves \& Fullan, 2012). Hattie's (2009) research has probably made the largest impression internationally. He argues that, amongst other things, (i) clear goals and learning outcomes, (ii) student engagement, and (iii) positive relationships between the teacher and the student are central to student learning. Similar findings have been made by other researchers with respect to which factors give rise to student success. However, we realise that specific teaching methods which work in every situation for every student cannot be found, such that these factors can be implemented in the classroom (Biesta, 2006; Håkansson, 2015). Every teacher and every school are subject to their own unique conditions, and that which worked for one group of students cannot be assumed will work for a different group. The way in which one might achieve successful teaching is thus always dependant on the individual teacher's ability to read the situation and to be able to deal with the unexpected. Biesta $(2001 ; 2006)$ described the above as the ability to deal with the unpredictable in one's teaching so that one can make situated decisions concerning what is best for each student's knowledge development/learning.

It is thus of some importance that we learn from teaching practitioners, so that we can increase our knowledge of how successful teaching can be carried out and thereby increase the quality of teaching and school results. The present study is part of an ongoing research project where 104 students and 20 teachers have been interviewed on the topic of 'successful teaching', from a variety of perspectives. The present paper treats the teachers' perspective, i.e., the teachers' descriptions of how they actively plan, manage, and deliver teaching so as to succeed in the areas of inclusion and knowledge development in their classrooms. The teachers taught 16 to 18-year-old students.

\section{Aim}

The aim of this paper is to contribute to our knowledge about the actions (how) which skilled teachers report are key to successful teaching with respect to inclusion and knowledge development.

Inclusion, in this study, refers to the situation where the teacher, in their daily teaching practice, creates the conditions where every student can participate and develop, according to each student's ability to engage in learning. Inclusion is not limited to those students who are in need of special support if they are to achieve what is expected of them; inclusion, in the present study, is viewed as a question of general pedagogic importance, where every student is included, even high-performing students (Persson \& Persson, 2016).

Knowledge development refers to the learning that students engage in, in accordance with the intention behind the teaching that is provided, and the achievement of learning outcomes. This reinforces and complements the concept of 'inclusion' since knowledge development must be present in any given learning situation (Carlgren, 2015). 


\section{Theoretical framework}

This qualitative study employs a phenomenological approach, as developed by Husserls (1900/2001), Heidegger (1927/2008), Merleau-Ponty (1945/2006), Schutz (1967/2002) and van Manen (1990; 2007). A number of researchers have contributed to the development of phenomenology as an experience-based philosophy. Schutz (1967/2002) describes the everyday life-world that we find ourselves in, for example, whilst attending school, as a practical-, social-, and historical world which, for the individual, instantiates reality. This reality is shared with others and is revealed to us by means of our experiences. Gallagher and Francesconi describe how phenomenology can be used in the context of education and teaching with the following observations:

Phenomenology focuses on experience in-the-world, it puts the teacher in a position to recognize his or her own epistemic responsibility. It is of fundamental importance that teacher and students become aware of, and take responsibility for, their perspectives on the world. Phenomenology therefore offers teachers a way to reflectively take into regard their own point of view, and their own way of concluding their relationship with the things of the world. (Gallagher \& Francesconi, 2012: 4).

Bengtsson (2005) submits that people's everyday life, (in the present case, the teaching provided by skilled teachers), is not only based on the empirical experiences which they have encountered, but it is also based on the experiences which have been shared with them, for example by colleagues, friends, or by means of educational courses of various kinds. From this perspective, the knowledge that informs the teacher's planning, delivery, and follow-up of their teaching is considered to be a part of their experienced life. Those things which constitute the conditions for their teaching and the degree to which their teaching is a success have a direct connection to things that lie outside the formal teaching situation. For example, more propitious conditions for teaching will exist if the teacher knows something about the student's every-day life. This may include knowledge of the student's hobbies, friendships with his peers, and family circumstances. Lilja describes such a situation as:

[...] a closely-knit relationship between life and the world. This entails that learning and how learning can be enabled in the classroom is described from a perspective where the student, teacher, time and space interact with each other and are dependent on each other. (Lilja, 2015: 41).

With reference to Lilja, we note that it is not possible to view knowledge or learning as solely 'cognitive' or 'objective' and independent of time and space. Both teachers and students are part of a social world where they interact and exchange experiences with each other inside and outside the classroom, before, during, and after the school day. Teachers and students support the teaching practice both socially and practically, but this practice is experienced individually.

Research within a phenomenological framework entails, in terms of epistemological considerations, that knowledge development takes place based on the participant's experience of practical- and social 'daily-life', in relation to the research object. In the present study, the assumption is made that knowledge of the research object is to be found in the teachers' descriptions of how they experience that their teaching successfully creates inclusion and knowledge development. 


\section{Method}

This research project was conducted in cooperation with a regional development centre which is funded by 10 municipalities located in southern Sweden. In each municipality, an education strategist assisted us in communicating with schools and school principals so that two teachers from each municipality could be chosen to participate in the study. For each municipality, one teacher from Grade 9 and one high school teacher were selected. The teachers all possessed 'proven ability" in successfully teaching in a way that developed their students' knowledge, taking into consideration each of their student's abilities. The teachers were then contacted and were informed of the general purpose of the study and then asked whether they wished to participate in the study. The teachers were also told that the research process would be subject to the Swedish Research Council's ethical code with respect to such research in terms of the ethical treatment of information, participant consent, confidentiality, and the use of the data collected during the study.

Data was collected during 20 interviews with the selected teachers between April, 2017, and April, 2018. The authors conducted classroom observations which were followed up on with interviews with the teachers. The purpose of conducting the classroom observations was to obtain an overall picture of how the teachers taught, but also to be able to identify any specific events which could then be brought up during the interviews. The interviews took place at the teachers' schools and were conducted according to an interview guide which consisted of 4 open questions which were complemented with follow-up questions. The open questions were:

- What characterizes a 'skilled teacher'?

- What do you do to adapt the lesson according to the individual student's needs?

- How do you create inclusive lessons that also contribute to each student's knowledge development?

- How do you motivate your students to learn new things?

The interviews were between 1 to 1.5 hours in duration. They were recorded and transcribed, and then subject to analysis. In the excerpts provided below, the source of the quotes are kept anonymous since they are attributed to "Teacher 1" and "Teacher 2", and so on. The excerpts have been slightly modified for readability, but no significant words or the meanings expressed therein have been changed. Beyond the inevitable changes that translation brings to the table.

\section{Analysis}

In every instance of data analysis within the framework of phenomenology, a hermeneutic process of interpretation takes place (Palmer, 1969). This includes interpretation of what was said during the interviews and what was observed during the classroom observations. The hermeneutic interpretation is always present in a phenomenological analysis, as we come to some understanding of how specific details of the interaction relate to the whole and vice versa. This entails that the analysis takes place on both a 'latent' level and at a 'manifest' level (Ricoeur, 1981).

\footnotetext{
${ }^{1}$ Proven ability refers to the fact that the school principals who made the selection of successful teachers based their selection on statistics that could confirm these teachers' students' good grade results and their students' perceived well-being by means of periodic surveys.
} 
The phenomenological method is often presented as a series of successive steps, but it is not the case that each step has to follow the next in a predetermined fashion. The different steps should be taken as independent of each other, by understanding them in a non-linear fashion (Spiegelberg, 1994). van Manen, for example, presents one method of analysis in this tradition in four steps: (i) Turning to the Nature of Lived Experience; (ii) Existential Investigation; (iii) Phenomenological Reflection; and (iv) Phenomenological Writing (van Manen, 1984: 42). In this study, 'Phenomenological Reflection' is used to perform a thematic analysis as per the following:

(iii) Phenomenological Reflection: Conducting a thematic analysis

- Uncovering thematic aspects in lifeworld descriptions

- Isolating thematic statements

- Composing linguistic transformations

- Gleaning thematic descriptions from (artistic) sources

- Determining essential themes (van Manen, 1984: 42)

The notion that the empirical material should come to the fore, in its own terms, is emphasised by van Manen (1984). 'Phenomenological Reflection', as a method, entails a movement back and forth between parts and the whole; where a holistic meaning (general structures) are characterised by means of limited, meaningful units (situated structures), and vice versa. The resultant structure which emerges during the analysis, in response to the aim of the study, is instantiated by the six themes which are presented below in the 'Results' section.

\section{Teaching proficiency}

This study was conducted in Sweden, but the traditions associated with the Swedish education system are not radically different to those of other countries. The education systems in the West are similar to each other in many respects. With respect to the research question concerning teaching and skilled teachers in relation to student performance, we note that this is central to a great deal of research that has been so far conducted in the $21^{\text {st }}$ century.

If we are to understand and evaluate a teacher's ability to teach, then this must take place in the light of explicit didactic- and ethical intentions and an examination of how these areas interact with each other. In this context, didactics refers to achieving student learning in accordance with the intentions behind the teaching that is provided, i.e., "[t]he degree to which achievement [of student learning] corresponds to the intended goals of the teaching" (Håkansson \& Sundberg, 2012: 53). The ethical dimension of teaching can be understood as 'good' teaching, in the sense that the teaching is accordance with the lesson's goals and in accordance with methods which can be ethically- and morally justified. Given this, we note that teaching may well be successful, but it may not necessarily be ethically or morally defensible (ibid). For example, a teacher might successfully teach about their personal political convictions, but this does not necessarily entail that such teaching is ethical. The teachers who participated in this study possess the ability to provide successful teaching that is both didactic and ethical.

At school, a student's learning is dependent on the way teaching is structured, and thus one may claim that the teaching (as an activity) is more complex than the learning which it is aimed at bringing about. The purpose of teaching is to promote learning in students who have different backgrounds so that they can develop their knowledge of different subject areas. 
Heidegger describes the relationship between teaching and learning in the following way:

Teaching is even more difficult than learning. We know that but we rarely think about it [...] Not because the teacher must have a large store of information, and have it always ready. Teaching is more difficult than learning because what teaching calls for is this: to let learn. The real teacher, in fact, lets nothing else learned than - learning. [...] The teacher is ahead of this apprentice in this alone, that he has still far more to learn than they - he has to learn to let them learn. (Heidegger, 1972: 356).

One might think that Heidegger's point does not support the notion that it is the teacher's job to teach their students so that they can achieve set goals. Furthermore, if this is to be possible, then specific subject content needs to be learnt; namely, content which is predetermined. However, I contest that Heidegger's point is that students should learn how to learn instead of learning something specific. This claim is in agreement with the overarching ideological purpose of the school system, to wit, the principal goal should be to teach the students how to learn (Deakin Crick, Stringher, \& Ren, 2014).

The complexity of teaching is not easily described in general terms, because it is a changeable phenomenon and, in many respects, creative and 'of the moment', since it takes place when people interact with each other. It is not possible to plan for every contingency in the classroom and to know what the results of such teaching will be in terms of evidence. As early as the 1970s, Gage (1978) claimed that teaching is an art form which is creative in its execution, even though it is based on scientific principles. These scientific principles must be our point of departure with respect to subject content and teaching methods, given the assumption that pre-determined teaching methods do not ensure that the teaching will be successful because, in the final analysis, the teaching that is provided is always dependent on the teacher's skillfulness and ability to read the situation and act accordingly.

For the past two decades, the issue of authoritarianism that is associated with teaching has been a subject of discussion. On the one hand, clear classroom management and the establishment of order in the classroom have been factors that contribute to learning success. However, on the other hand, a freer pedagogic attitude has also been suggested, where the main message has been that the students should be free to find their own way to learning situations which are based on their own interests. (Carlgren, 2015; Biesta, 2017). In Biesta's The Rediscovery of Teaching (2017), he presents a number of ideas concerning how teacherdirected teaching can progressively (although remaining somewhat 'authoritarian') can lead to the student's emancipatory development. He calls this 'Progressive Education', whereby acts of dissent the student can develop their knowledge which is based on the desire to learn, in an adult way, to be a free and independent subject in the world.

\section{The teacher's importance}

Hargreaves and Fullan (2012) state that questions concerning teaching and the teacher's importance in the classroom have never had such a central role in research and school practice as they do now. Skilful teachers are important agents of change with respect to quality teaching which goes beyond teaching methods and available resources:

There is widespread agreement now that of all the factors inside the school that 
affect children's learning and achievement, the most important is the teacher - not standards, assessments, resources, or even the school's leadership, but the quality of teacher. Teachers really matter. (Hargreaves \& Fullan, 2012: xii).

In one literature review, Hattie (2003) identified that which characterises skilful teachers by making a comparison between 'experienced teachers' and 'expert teachers'. According to Hattie, subject knowledge is necessary for all teachers, irrespective of whether they are inexperienced, experienced, or excellent teachers. Consequently, subject knowledge is not a sufficient criterion in the identification of excellent teachers. What identifies an excellent teacher is that they:

- focus on what is important in the teaching session

- adapt their teaching to the prevailing situation

- create a good environment for learning

- engage on an emotional level with their work and their students

For many years, the ability to create a good learning environment has been a common denominator for several studies into what characterises a skilful teacher. For example, Purkey (1992) points out that skilful teachers have the ability to create a good and respectful environment where learning can take place. This author also claims that the foundations of teaching are instantiated by a willingness to invite the students to learn, an invitation that communicates respect, trust, optimism, and gives opportunities for success. This (challenging) teaching ability is described by van Manen (1991) in The Tact of Teaching where one is encouraged to search for understanding of the teacher's professional skill. van Manen claims that the question of which learning processes (teaching methods) that can be used so as to be successful in an educational situation has a different answer every time it is asked. This is the case because the teacher must interpret what the student knows in each situation in the classroom and then decide on what the situation demands, when something should take place, at what pace, and how this should be done. The Tact of Teaching argues that a skilled teacher has the ability to understand that which is important and meaningful in the student's life-world in specific situations.

In a comprehensive review of the literature, Nordenbo et al. (2008) present a number of different competencies which teachers have stated are of importance to successful teaching and contribute to student learning. Their study reports on three important competencies: Leadership, competence and didactic competence. There are striking similarities between Nordenbo et al.'s results and other meta-studies and literature reviews, for example, Hattie's (2009) and Martin and Dowson's (2009) work. In summary, research on skilled teachers shows that the most important success factor for teaching is the relationship between the teacher and the student. A good relationship establishes a good foundation for the student's learning. This relationship must, in all respects, be a relationship of trust and respectful engagement, which, amongst other things, is based on authenticity, trust, and honesty (Aspelin, 2017).

\section{Results}

A point of departure shared by the participating teachers was the point that good knowledge of the subject content was fundamental to being able to produce successful teaching. The teachers also agreed that this was a necessary, but not sufficient, condition. Other things were needed, including "a great deal of building relationships. This is because if I think that I can 
just enter [the classroom] and keep to the facts, then it just doesn't work, of course." (Teacher E). Successful teaching demands an attitude and set of behaviours which goes beyond possessing knowledge of a particular subject content. These include issues that emerge in the interaction between the teacher's and the student's life-worlds. Below, we present the six themes which were identified during the analysis.

\section{By actively and systematically creating relationships}

The participating teachers reported that the most important factor for successful teaching was the existence of a good relationship with their students. However, this is not something that can be taken for granted or merely emerges after the passing of time as the teacher gets to know more about the students. During the interviews, the establishment of relationships was a conscious, systematic, and active behaviour on the teacher's part. This entailed the creation of trust and the notion that "if they are seen, then they are someone" (Teacher L). Most of the teachers reported that, amongst other things, they would often station themselves near the students' lockers and walk with their students to the classroom. During this walk, the teacher would ask the student how their day had been and also allow the student time to ask any questions of the teacher. Primarily, this action showed that the teacher cared about the students. In the excerpt below, we are provided with another example of what a teacher does when they look up their students in an effort to make meaningful contact with the students. Note that teaching matters or school performance issues are not referred to, but rather, the teacher attempts to conduct a conversation with the student in an effort to learn about the student at the beginning of the school term:

[I] know myself when I get frustrated because there are students in the classroom who I have not paid attention to and then I thought, no, the only thing to do was to set up an Excel file, a class list. I mark them off [on the list] after I have given them some private attention which actually doesn't have anything to do with my teaching and it can be when they are waiting outside the classroom and I walk past and just say: "How was football training yesterday?" or whatever, and then I mark off that student [on the list] and so that becomes the first step in trying to systematise such a thing. (Teacher B).

The systematic approach which the teachers employed to create relationships with the students was described in different ways during the interviews. Some teachers reported that when they get a new class of students, they do not begin with teaching them until the teacher has learnt the names of the students and has learnt what every student is interested in. This may take several days to accomplish. Most of the teachers in this study claimed that knowledge about their students enabled them to initiate conversations with them and to establish a point of departure in their teaching. The challenge was to find a balance between being a professional teacher who is responsible for the student's knowledge development and being an interested fellow human being. One of the teachers reported that they "try to find an opening, about something that the student likes, something that the student knows that I know. So we don't talk just about the subject. I would not think that it was fun to be a teacher if I was just the Spanish teacher [name], instead, I want to be a human being [name] who teaches Spanish." (Teacher M). In the final excerpt on this theme given below, we note an example of how a teacher gives themselves homework on learning at least one thing about every new student that they have within a week:

Interviewer: With respect to 'seeing' every student you talk to, how does one do 
that in practice?

Teacher $\mathrm{H}$ : Actually, I give myself homework, so that for every student who I teach, I must know at least one thing about them, and this might include knowing what their dog's name is, which handball team they play for, which hockey team they support, what the name of their family is, or where they live [...] I do this as real homework for myself.

\section{By demonstrating that the teacher wants to be with the student, here and now}

Throughout the interviews, the teachers also reported how important it is to demonstrate to their students that they, as teachers, want to be with the students, here and now. However, this sentiment must be genuine; one should not merely act out a role. This is based on liking one's work and one's students and showing this; but also allowing oneself to have a 'bad day' on occasion. The teachers stated that the students immediately see through the teacher if the teacher is having a bad day and is 'not in the mood': "[T]hen one is not convincing if one tries to play a role which I am not up to, because that is simply not who I am" (Teacher N). This entails that one demonstrates that one thinks that the work to be done is important and that the students are important for the teacher and for each other in the classroom. The participating teachers claimed that it is easier to create joy and curiosity in the classroom if the teachers demonstrate that they want to be there with the students who they have in front of them. The teacher's behaviour is then reflected back by the students:

Interviewer: What do you do to establish this sense of curiosity which you refer to? Teacher K: [l] want things to be such that the students say "I wonder what we will study today?" But also that they should see that I really think that it is fun, then you don't reach everyone with this approach. But I think that it is very important that you show your joy, that they mirror my sentiment I think.

By demonstrating that they wish to be together with their students, the teachers also show that the work that they do together is important. The exercises that they work with do not only engage the students, but also the teacher. On several occasions, the participating teachers reported that they complete classroom assignments together with the students, for example when a text is to be written or mathematical problems are to be solved. This does not necessarily include exactly the same assignments as the students, but, rather, assignments which the teacher wishes to complete so as to demonstrate that it is fun and is something that is relevant to the teacher too. The excerpts below show how important it is for teachers to demonstrate that they really want to teach the particular students who are in front of them in the classroom. In the first excerpt, the teacher recounts a conversation between the teacher and a newly-qualified teacher who has asked for some advice concerning successful teaching. In the second excerpt, the teacher provides an example taken from a meeting with a class of students where they discussed what it is like to be a teacher:

Interviewer: What is it that you do to accomplish this?

Teacher Q: I would like to say that I am curious, and that is quite apparent too. And I believe that it is probably obvious that I really enjoy my subject. I had a former student who started exactly here, that year when he started. He then came to me and asked, he is very good at Math and such things, so there were no problems, but he asked me just about: "What should I do?" and my spontaneous answer was that you should show it in all of your body language that there is nowhere else in the whole world you would rather be than in the here and now [in the classroom], you must show this. If you don't want to [do this], then it is not possible to just act it 
out. It is in the attitude of "Yes, now I can be together with you all!" Show that attitude in some way.

I think that it is a great job. I think that you should think that too, because if you don't think that, then the students will notice it, they notice if you are not happy with the job and then it is not easy. I have to be able to say: "What a great job I have. I get to meet you three times a week." You must be able to say this and mean it too. I once had a class, they have finished school now, they said: "[Name], why are you always so happy when you have us?" And I replied: "Yes, I have class with you, and I even get paid to do it. It is the best job in the word of course." They thought that it was nice to hear that. Working with people, of course, is very stimulating. (Teacher C).

\section{By continually striving to become a better teacher and demonstrating this}

The analysis of the interviews revealed that a continual striving to become a better teacher, and showing this to their students, was a feature common to the teachers who participated in this study. With respect to the teachers' remarks on this theme, what they had in common was that a student's achievements, irrespective of their ability, are the result of the teacher's teaching efforts. Two points were raised in this context: (i) the teachers systematically investigated their teaching practices so as to improve these practices, and (ii) an internal motivation to develop as a person and become a better teacher which stimulated the teachers and allowed them to feel that they were doing a good job. These two points are, of course, related to each other and thus it is no easy task to determine which is the cause and which is the effect. Notwithstanding this, both reveal an attitude where the teachers do not view themselves as 'finished' teachers who merely work according to a routine Instead, they believe that their teaching practices can always be improved upon. They also acknowledge that only they can change and develop their teaching practices themselves and achieve success:

I get the feeling that I have a good relationship with this class, or a very good relationship with the next. I am open with respect to the whole process, how I think about teaching, grading, I almost touch on knowledge development and how the students understand this. I ask them: "Am I thinking correctly?" and similar questions, I want feedback so I can improve. [...] I don't really like some type of written evaluation of my teaching at the end of the year, that gives me absolutely nothing. If I get this during the class, then it can help, so I shouldn't get it then [at the end of the year]. Because then it would be too late of course to be able to show that I change in response to what they thought. "This, we thought was very good", then I can at least go back a bit and show that I also like it, so that it isn't just empty words. Consequently, I strive to be really open and wish to improve as much as possible, and then you have to reveal your human side too. (Teacher B).

By showing that they want to improve their teaching, teachers indicate the seriousness of the situation to the students. According to the teachers, they note that the students adopt a different attitude towards classroom teaching in response to observing how their teacher continually strives to improve. This is noted when the students report that they feel that they are participating and feel included in the teaching, by means of continual evaluation and ministudies which aim to improve teaching based on the students' experiences. "This creates respect for the situation, you know, even if this was not the actual aim, it is what I am 
interested in at the end of the day, it is me who wants to develop" (Teacher J). The teachers also reported that they sometimes ask themselves what they can do to improve "next term", "next week", or "tomorrow". Further to the present theme, we note that the teachers did not focus on external resources in their attempt to improve their teaching. Instead, 'here and now' was the time to change things:

[I] have made many mistakes and I still do. But I am quite reflective over my teaching, if something happens or it does not turn out to be what I had expected and I have a student who is not performing as they perhaps should, then I think about it a lot. I don't blame external factors so much, instead, I think about what I could have done differently. This is because I really believe that you should rely on yourself since the person who can influence the situation is only yourself. (Teacher $\mathrm{M})$.

\section{By sharing responsibility for learning with the students}

Another factor relevant to teaching that is inclusive and develops the student's knowledge is sharing the responsibility for learning between the teacher and the student. It is not only the student's responsibility to learn, but neither is it solely the teacher's responsibility that the student learns either. In the interviews with the teachers, it was reported that the teachers create a climate of learning together with the students, where they collectively take on responsibility for the teaching that is provided and for each student's learning. Together, teachers and students identified the factors which inform quality teaching. "It is about leadership, of course, whether you can relinquish some leadership" (Teacher $L$ ). This includes a mutual decision about how the teacher wants things to proceed in the classroom and how the students want things to proceed, so as to ensure that classroom practices are optimised by establishing rules and ways of working together. However, the teachers made a point of saying that not everything is done according to the students' wishes; in the final analysis, the teacher is ultimately responsible for the teaching that is provided. In summary, the teachers clearly show that they are responsible and that they have certain expectations, whilst simultaneously humbly acknowledging that the students play a role in this process too:

You have to find some common agreement. This is what I think, I think perhaps, I know in my mind how I think things should be in the classroom, but I don't need to tell them this, I don't need to say that "these are my rules which you must follow". Instead, we make up the rules together, "How do you think you should behave in the classroom? What do you think are the most important things to do?" And in Swedish this is simple; you can use a short story for example, and there are loads of them, of course. And from the short story, they draw their own conclusions and set up the class rules or the Swedish group's rules. So then you have rules together with them, and later you might have to prioritise too, by saying "this is very important for me". (Teacher S).

A shared responsibility for learning also involves creating teaching situations where the student feels comfortable enough to ask questions or provide answers, even if they are incorrect. It is important to establish a climate in the classroom where every question is considered to be of value. The teachers report that, in the beginning, this can be difficult to accomplish. It is a shared responsibility between the teacher and the students if such a climate is to be properly established. There is a great responsibility placed on the students' shoulders, as they allow for a safe and secure conversational space to emerge in the classroom, where every student can feel included and be offered opportunity to express themselves. But most of all, it is the responsibility of the teacher, who must be unwavering in 
establishing this principle from the beginning, so that a good and open classroom climate can emerge:

Interviewer: How do you establish this in your teaching or in the classroom?

Teacher $\mathrm{H}$ : In the classroom? Well, the students know I am an adult, I say what goes on in the classroom. If I allow flicks on the back or small snide remarks then it becomes uncomfortable of course, doesn't it? If I allow someone to grin or laugh at someone else when they speak Spanish in my classroom, then it is obvious that they will not do it next time. Instead, I must clearly state from the beginning that this is not acceptable, this is what the rules are. And we talked about this quite a lot at the beginning, about what rules we should have in the classroom. In this way, you do it together with them.

\section{By creating learning opportunities}

The creation of learning opportunities entails a certain compliance with the student groups with respect to teaching which is planned in advance and spontaneous, extemporaneous teaching. The ability to find a balance between planned teaching and spontaneous teaching is described by the teachers as a teaching method which is adapted to the students, not a situation where the student group is provided with a pre-determined teaching methodology. This adaptability entails that, in most cases, several, parallel teaching methods that resonate with the students' different needs and abilities are frequently used. None of the teachers claimed that there is one specific method which works in every teaching situation. If one is to create learning opportunities and include every student, then the planning for such lessons must take every student in the class into account, since it is not advisable to think that one particular lesson plan will suit every student's learning situation. Further on this theme, the teachers provided examples of how important it is "to always have assignments ready for all levels of student" (Teacher B) and to work on achieving individual goals which are suited to individual students. What frequently emerged during the interviews was the idea that the teacher should comply with the student group and dare to let go of a set lesson plan if the situation so demands. Planning should not become a pedagogic obstacle, and if the lesson plan is not working, then one should abandon it:

[Y]ou can never never make progress faster than the pace of the students. Working faster than the students is completely meaningless, if the students are not with you and if they don't understand, then it just doesn't work, of course. The student groups are different in their abilities. There might be certain groups where I can easily go through twelve themes in a year or so, whilst with other groups you just about have time to cover eight themes, because you have to get the students to follow you. [...] I have never started a term and I have absolutely never started a school year with a complete detailed lesson plan for each week. Of course, there is a plan, yes there is, and the students are included in it. But then things happen on the way which results in me not being able to say that we will finish, for example, Week 47 this [theme]. Something fantastic might happen, a good idea might be offered by a student which might lead to a different exercise in Swedish, and then we do it. (Teacher A).

Inclusion is described as an opportunity for everyone to learn. However, this goal is not easily achievable in every case. With respect to inclusion for students who have poor school performance or for students who suffer from some form of disability, the teacher has to be creative whilst teaching and sometimes make a 'didactic case' for involving the other students, so that everyone is provided with the opportunity to learn at different levels: 
I like this notion of 'inclusion'. I think that we should all be able to be in the same space, the special school has always been involved in our school and in the first years they were in my class, this solution was decided upon and I like it. It is possible to create the ultimate group project in such cases. They received a text by Agatha Christie in English which they were tasked to translate into Swedish. In the group, there was a girl who attended special school but she could write passably well, no capital letters or small letters, no sentences, but despite this it was possible to understand what she wrote. And when this group got together the solution was thus: "Can't you write a text and then I can make a clean copy of it later, and so you can translate and you can make a pretty layout of the text." In such a case, I feel that one has succeeded, everyone in the group was challenged. [...] I think it is quite fun to succeed in getting everyone to be involved. (Teacher Q).

\section{By establishing trust and a sense of security}

According to the teachers who were interviewed, trust and a sense of security are foundational to successful teaching. This includes "looking for things that are right, instead of looking for things that are wrong" and focusing on "what they can develop, not on what they can do" (Teacher B). By paying attention to that which is 'right' and that which it is possible for the students to develop in, the teacher creates trust and a sense of security. The teachers reported that the work that they do to create a sense of security is directed at making the classroom, as a learning environment, safe. Every student is given the opportunity to speak, there are no repercussions if a student provides an incorrect answer, and students are allowed to have a 'bad day' on occasion, knowing that it is acceptable for them to come to class and be left in peace. "They come here, of course, and that is very important. They always do something, but most importantly, they are here." (Teacher D). Trust and a sense of security also entails that the students trust the teacher and know that there is a plan, and that the teacher believes in the students and trusts them:

It is very important that they feel that "ok, when we get there they know that I have a plan for what we will do, we might not know everything today, but we know that there is a bigger context" [...] Now I really enjoy my job and my students, but I also want them to know that: "It is important for me that things go well for you, what do we do now - can we help each other out?" I am here for them and I am not just someone who just talks about it. (Teacher F).

Teacher $\mathrm{J}$ : [Y]ou should relax in class and feel calm in the classroom, safe in the classroom and not afraid of what might happen.

Interviewer: Describe what successful teaching is for you.

Teacher $\mathrm{J}$ : For me, it is reaching out to the students, that the students rely on me. And that I can feel that I connect with the students in conversation, that we have some form of mutual respect for each other as human beings.

\section{Final discussion}

One distinguishing feature found with the teachers who participated in the study was their holistic approach to teaching. Teaching is not only part of a scheduled activity, it is an ongoing process which takes place during the whole time that the teacher is at school and interacts with students. It may take place during breaks when a student does not have a scheduled class or in passing, in the dining room, the school corridor, or elsewhere. Such interaction does not take place at the cost of the teacher's own rest periods, but is considered a natural 
part of the school day. Another point worth mentioning is that only 2 of the 20 teachers who were interviewed mentioned 'a lack of time' as interfering with their teaching assignment. During the almost 30 hours of interviews with the teachers, during which many different topics were touched upon, a lack of time was not a factor which hindered the teachers in the performance of their duties for the other 18 teachers.

The interviews with the 20 participating teachers revealed that there exists a great deal of agreement within this group of professionals. The themes which were identified in the 'Results' section were of importance for the whole group of teachers with respect to how they enable inclusion and teaching which develops their students' knowledge. Primarily, the teachers emphasised that good relationships are fundamental to student inclusion and creating opportunities where students can develop their knowledge. The first theme addressed in the 'Results' section of this paper, By actively and systematically creating relationships, can thus be considered as an overarching theme because relationships are a necessary pre-condition for (i) being able to share responsibility for learning with the students, (ii) creating learning opportunities, and (iii) establishing trust and a sense of security.

Each of the themes that are identified in the 'Results' section are distinct from each other, but some of them are related to others in several different ways. This should come as no surprise when one considers that the teachers described complex situations in their daily teaching routines. On several occasions, the teachers stated: "But it all fits together some way". For example, it is no easy task to know whether the theme - demonstration that the teacher wants to be with the student, here and now - constitutes a pre-condition for establishing good relationships with the students or whether existing good relationships cause the teachers to enjoy their professional role more so and thus enables them to demonstrate that they wish to be with the students, there and then. A similar line of reasoning can be made with respect to the establishment of trust and a sense of security. The one theme that does not touch on the other themes in such a clear manner is a continual striving to become a better teacher and demonstration of the same. This theme is, on the whole, central to the results of this study and the teachers' efforts in this regard ("to be become a better teacher") are reflected in their teaching and thereby influences student motivation. When teachers demonstrate that they strive to improve their own teaching, students take note of this. It then becomes easier for the teacher to conduct conversations with students and to get them to strive after higher rates of class attendance and better academic performance.

All of the teachers who participated in this study claimed that the foundation for successful teaching is where the teacher is responsible for the students' inclusion, in such a way that each student is provided opportunities for knowledge development. This is the case irrespective of what level of attainment the student has achieved. However, as the results of this study show, the teacher's knowledge of the subject matter is a necessary - but not sufficient - condition for success. One must alternate between (i) a pre-determined direction which is indicated by the teacher and (ii) humble interaction with is based on mutual respect where the student is provided the opportunity to embrace their freedom and be responsible for their own existence in the world. The teachers' reports generally coincide with that which Biesta (2017) calls 'progressive teaching'. Such teaching can be connected to the emancipatory ambitions of education. This entails "creating existential possibilities through which students can encounter their freedom, can encounter the 'call' to exist in the world in a grown-up way, as subject" (Biesta, 2017: 6). With respect to every-day teaching practices, the 
results of this study indicate that successful teaching is concerned with the teacher's ability to (i) read how students feel in different situations, (ii) know when something has to be done, (iii) know at what pace something must be done, and (iv) know how this should be done. Consequently, we note this is very similar to what van Manen (1991) writes in The Tact of Teaching.

In conclusion, we claim that it is important to present a theoretical perspective, such as found in the phenomenological approach, to the investigation of issues related to teaching in today's school system. Successful teaching should be documented and be interpreted by professionals, based on their previous experience. A flexible approach should be adopted so that certain analytical methods and theories do not pose an obstacle to the identification of certain factors which are necessary for inclusion and knowledge development. Schutz (1967/2002) claims that it is necessary to be flexible with respect to one's object of study and that one should adapt the research method according to one's reality, and not the other way round.

In this study, phenomenology has allowed the researcher to be open-minded during the interviews with the teachers and to be flexible with respect to the analysis of these interviews, at both the latent level and the manifest level. One deviation has been made, however, from the phenomenological approach described in the theoretical section of this study. This deviation refers to the quantitative analysis that was performed during the identification of the themes presented above. The themes on which the results of this study are based were those themes which were most frequently referred to or mentioned during the interviews, i.e., that which is representative for the selected group of teachers.

\section{References}

Aspelin, J. (2017). We can recite it in chorus now!: An interactionist approach to the teacher-student relationship and teachers' relational competence. Classroom Discourse. Vol. 8(1). pp. 55-70. https://doi.org/10.1080/19463014.2016.1271991

Bengtsson, J. (2005). En livsvärldsansats för pedagogisk forskning. I J. Bengtsson (eds.). Med livsvärlden som grund. Lund: Studentlitteratur.

Biesta, G. (2001). Preparing for the incalculable. Deconstruction, justice, and the question of education. In G. Biesta \& D. Egéa-Kuehne (eds.) Derrida \& Education. London: Routledge.

Biesta, G. (2006). Beyond learning. Democratic education for a human future. Colorado: Paradigm Publishers.

Biesta, G. (2017). The rediscovery of teaching. New York: Routledge.

https://doi.org/10.4324/9781315617497

Carlgren, I. (2015). Kunskapskulturer och undervisningspraktiker. Göteborg: Daidalos.

Deaking Crick, R., Stringher, C. \& Ren, K. (2014). Learning to learn: International perspectives from theory and practice. New York: Routledge. https://doi.org/10.4324/9780203078044

Gage, N. (1978). The scientific basis of the art of teaching. New York: Teachers College Press.

Gallagher, S \& Francesconi, D. (2012). Teaching phenomenology to qualitative researchers, cognitive scientists, and phenomenologists. Indo-Pacific Journal of Phenomenology. Vol. 12. (Special 
Edition). pp. 1-10.

Hattie, J. (2003). Teachers make a difference. What is the research evidence? Paper presentation. Melbourne: ACER Research Conference.

Hattie, J. (2009). Visible learning: A synthesis of over 800 meta-analyses relating to achievement. London: Routledge. https://doi.org/10.4324/9780203887332

Hargreaves, A. \& Fullan, M. (2012). Professional capital: Transforming teaching in every school. New York: Routledge.

Heidegger, M. (1927/2008). Being and time. London: Harper Perennial Modern Classics.

Heidegger, M. (1972). What calls for thinking? In M. Heidegger, Basic writings. New York: Harper \& Row.

Husserl, E. (1900/2001). Logical investigations. Vol I-III. New York: Routledge.

Håkansson, J. (2015). Structured teaching and classroom management - the solution for the decline of Swedish school results? Conclusions drawn from a comparative meta-synthesis of teaching and learning. Teachers and teaching: Theory and practice. Vol. 21 (5). pp. 584-602. https://doi.org/10.1080/13540602.2014.995479

Håkansson, J. \& Sundberg, D. (2012). Utmärkt undervisning - framgångsfaktorer i svensk och internationell belysning. Stockholm: Natur \& Kultur.

Lilja, A. (2015). Hur lärande kan möjliggöras och hindras i skolan. In Bengtsson, J. \& Berntsson I. (eds.) Lärande ur ett livsvärldsperspektiv, pp. 35-53. Malmö: Gleerups.

Martin, A. \& Dowson, M. (2009). Interpersonal relationships, motivation, engagement and achievement: Yields for theory, current issues and educational practice. Review of Educational Research. Vol. 79 (1). pp. 327-365. https://doi.org/10.3102/0034654308325583

Merleau-Ponty, M. (1945/2006). Phenomenology of perception. London: Routledge.

Nordenbo, S-E., Søgaard Larsen, M., Tiftikci, N., Wendt, E., \& Østergaard, S. (2008). Teacher competences and Student achievement in pre-School and school. A systematic review carried out for the Ministry of Education and Research, Oslo. Copenhagen: University of Aarhus.

Palmer, R. E. (1969). Hermeneutics: Interpretation theory in Schleiermacher, Dilthey, Heidegger, and Gadamer. Evanston: Northwestern University Press.

Persson, B. \& Persson, E. (2016). Inkludering och socialt kapital - skolan och ungdomars välbefinnande. Lund: Studentlitteratur.

Purkey, W.W. (1992). An introduction to invitational theory. Journal of Invitation Theory and Practice. Vol. 19 (1). pp. 5-15.

Ricoeur, Paul (1981). Interpretation theory - Discourse and the surplus of meaning. Texas: Christian University Press.

Schutz, A. (1967/2002). The phenomenology of the social world. Evanston: Northwestern University Press. 
Spiegelberg, H. (1994). The phenomenological movement $-A$ historical introduction. ( ${ }^{\text {rd }}$ edition). London: Kluwer Academic Publishers Group. https://doi.org/10.1007/978-94-009-7491-3_1

The Swedish Research Council (2002). Forskningsetiska principer inom humanistisksamhällsvetenskaplig forskning.

van Manen, M. (1984). Practicing phenomenological writing. The University of Alberta. From: https://ejournals.library.ualberta.ca/index.php/pandp/article/view/14931/11752

van Manen, M. (1990). Researching lived experience: Human science for an action sensitive pedagogy $\left(2^{\text {nd }}\right.$ edition). New York: State University of New York Press.

van Manen, M. (1991). The tact of teaching: The meaning of pedagogical thoughtfulness. The University of Western Ontario: The Althouse Press.

van Manen, M. (2007). Phenomenology of practice. Phenomenology \& Practice, Vol 1 (2007), No 1, pp 11-30. https://doi.org/10.29173/pandpr19803 